\title{
Dahlia parvibracteata (Asteraceae, Coreopsideae), a New Species from Guerrero, Mexico
}

\author{
Dayle E. Saar and Paul D. Sørensen \\ Department of Biological Sciences, Northern Illinois University, DeKalb, \\ Illinois 60115-2861, U.S.A.
}

Abstract. Dahlia parvibracteata (Asteraceae, Coreopsideae), a new species from Guerrero, Mexico, is described and illustrated. It is distinguished by its numerous flowers on terminal or axillary stems, either borne singly on long peduncles or on short-branching naked stems held above the foliage, and by its narrowly spatulate to oblong-lanceolate outer involucral bracts. This species falls within the natural range for the genus, and is morphologically closest to $D$. moorei, although there are distinct differences.

Resumen. Se describe e ilustra Dahlia parvibracteata (Asteraceae, Coreopsideae), una especie nueva de Guerrero, México. Se distingue por sus flores numerosas dispuestas en tallos terminales o axilares, ya sea solitarios en pedúnculos largos o en tallos desnudos cortamente ramificados y sostenidos por encima del follaje, y por sus brácteas involucrales externas angostamente espatuladas a oblongo-lanceoladas. Esta especie se encuentra dentro del rango natural del género y es morfológicamente cercana a D. moorei, aunque existen diferencias marcadas.

While collecting material from wild populations of Dahlia to expand natural history information and for cytological and molecular analyses of the genus, we have discovered an undescribed species from northern Guerrero, Mexico. It was observed growing from soil trapped among volcanic rocks and rubble in sun, partial shade, and filtered light.

Dahlia parvibracteata Saar \& P. D. Sørensen, sp. nov. TYPE: Mexico. Guerrero: approximately $12 \mathrm{~km} \mathrm{~N}$ of Tasco, along Mex 55, just $\mathrm{N}$ of intersection of Mex 95 to Cuernavaca, 1820 $\mathrm{m}$, in zone of fan palm, Buddleja, Acacia, and Quercus, 15 Sep. 1995, J. P. Hjerting, D. E. Saar \& P. D. Sørensen 95-128 (holotype, MEXU; isotypes, C, DEK, F, IEB, MO, TEX). Figure 1 .

Herba perennis $0.8-1.5 \mathrm{~m}$ alta. Folia pinnata vel bipinnata. Capitula numerosa $5-8 \mathrm{~cm}$ diam.; squamis exterioribus involucri reflexis sub anthesi, anguste spathulatis vel oblongis, 9-14 mm longis, 2-3 mm latis. Flores radii corollis ligulatis lavandulis. Chromosomatum numerus: $n$ $=16$.

Herbaceous perennial from tuberous rootstock, several erect stems, $0.8-1.5 \mathrm{~m}$, generally taller with increasing sun exposure. Stems reddish but variable, short pubescent, internodes hollow with nodes imperfectly solid. Median leaves 17.5-28 cm long including petioles, bipinnate with stipels frequently at first rachis node (Fig. 1, lower left), becoming merely pinnate without stipels to simple at the base of the flowering portion; primary pinnae 7 to 9 ; blades strigose below, particularly along the midrib, margins serrate and ciliate. Flowers numerous on terminal or axillary stems, either borne singly on long peduncles or 1 to 7 on short-branching naked stems held above the foliage. Capitulum $5-8 \mathrm{~cm}$ diam., including rays; disc florets fertile, tubular, yellow; ray florets sterile, ligules 7 to 8 (9), light lavender with veins abaxially darkened. Inner involucral bracts 7 or $8,9-16 \times 4-7.5 \mathrm{~mm}$. Outer involucral bracts 5 or 6 , narrowly spatulate to oblong-lanceolate, 9-14 × 2-3 mm, reflexed at anthesis, projected from a flat and somewhat disk-like capitulum base. Flowering (1995) occurs August through September. Achenes black, 9.5-12 × 1.1$2.8 \mathrm{~mm}$. Chromosome number: $n=16$.

An additional population was observed and sampled 16 September 1995 (Hjerting, Saar \& Sørensen 95-131), growing among thickets along a fencerow, approximately $0.4 \mathrm{~km}$ north of the type locality. A third population was located about $1 \mathrm{~km}$ south of the type locality, but its position high on a ledge prevented its collection.

The specific epithet, parvibracteata, draws attention to the small, narrow outer involucral bracts, which twist somewhat, begin to bend outward from the inner bracts, and elongate beyond the flower bud prior to its opening. The result is an almost spider-like appearance (Fig. 2). This new taxon is tentatively placed in section Dahlia according to the sectional key provided by Sørensen (1969: 322 ), by its herbaceous habit, solid petioles, and pinnules opposite on the rachilla. However, this 


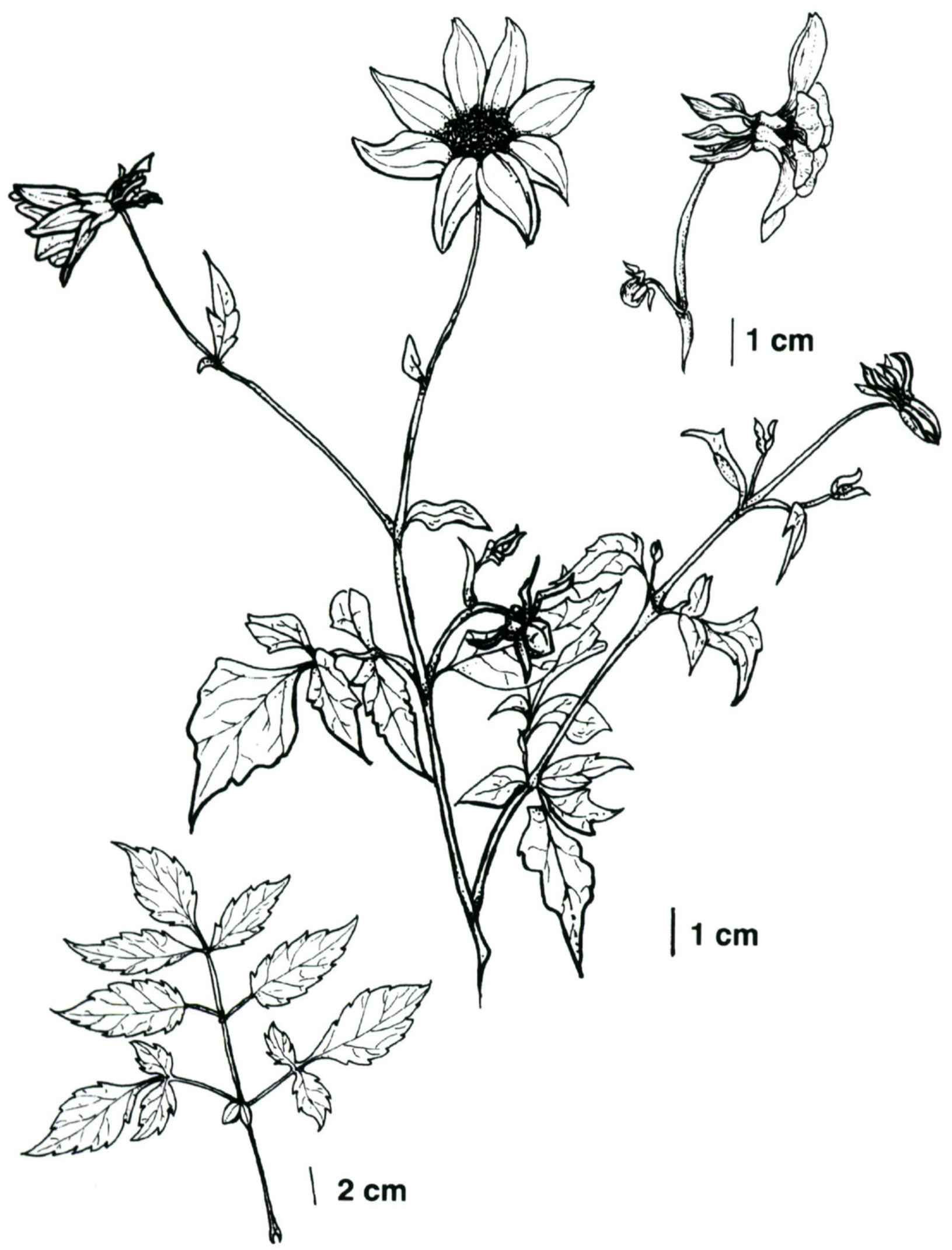

Figure 1. Dahlia parvibracteata Saar \& P. D. Sørensen. - Center, habit. - Lower left, median leaf with stipels. - Top right, flower head and bracts. Drawn from type specimens. 


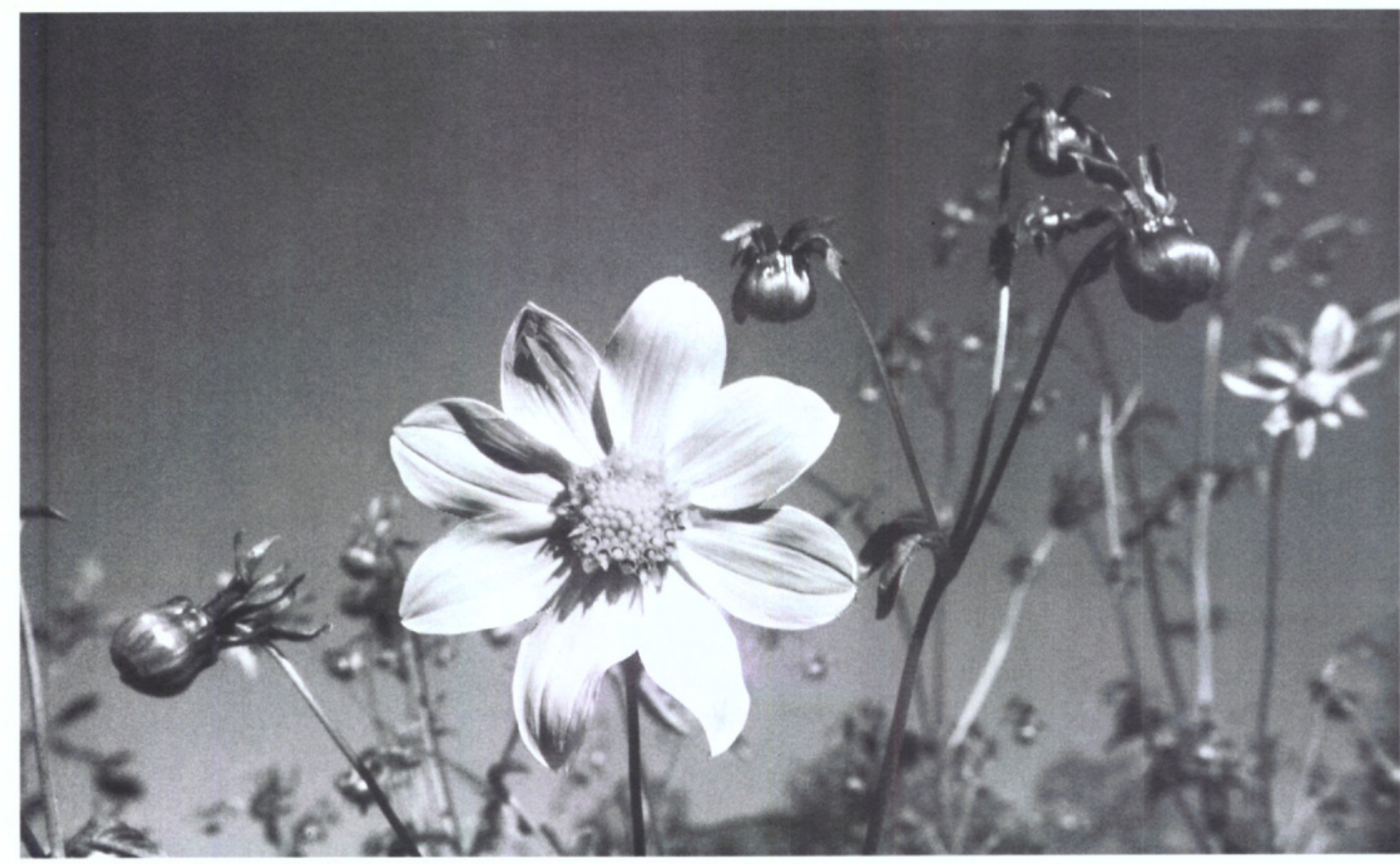

Figure 2. Unopened flower heads with developing outer involucral bracts exhibit spider-like appearance. Photograph of cultivated plants grown from seed collected at type locality with characters resembling those observed in natural habitat.

placement should be considered provisional, pending molecular analyses of several species of Dahlia as part of a phylogenetic study currently in progress by the first author. Within section Dahlia, D. parvibracteata has outer involucral bracts reflexed at anthesis, compound median leaves, lavender ray florets, wingless petioles, and leaves and stems that are not densely pubescent or pilose (some trichomes present). The key to species can be amended to include $D$. parvibracteata by rewriting the first half of couplet "G" (Sørenson, 1969: 324) and making the additions as follows:

G. Outer involucral bracts $9-17 \times 1.5-4 \mathrm{~mm}$, flagelliform to narrowly spatulate to oblong-lanceolate, tips obtuse to long-attenuate.

+ Outer involucral bracts $10-17 \mathrm{~mm}$ in length, long-attenuate, broadest at or near the base. Achenes constricted slightly below the summit to form a black disc less than $1 \mathrm{~mm}$ wide and barely $0.4 \mathrm{~mm}$ high ........ D. moorei

+ Outer involucral bracts obtuse, 9-14 mm long, narrowly spatulate to oblong-lanceolate. Achenes without black disc . . D. parvibracteata

Although $D$. parvibracteata seems similar to $D$. moorei as suggested by the above key, there are other distinguishing characters as well. Dahlia moorei has purple style branches; $D$. parvibracteata has off-white branches. The apices of the terminal leaf segments are long acuminate on D. moorei; those of $D$. parvibracteata are acute to broadly acuminate. Stipels are fairly uncommon among plant species bearing compound leaves, but they occur frequently throughout this genus, including both of these species. It should also be noted that D. moor$e i$ is known only from the type specimens, collected in Barranca de San Vicente, northwestern Hidalgo, Mexico, 1949 (Sherff, 1951).

The observed populations of D. parvibracteata fall within the natural distribution of the genus and are sympatric with the wide-ranging $D$. coccinea, which is distinguished by its ray florets that may be yellow, orange, red, or blackish scarlet (never lavender). Altogether, with the publication of this taxon, there are 30 published species of Dahlia, not including the hybrid cultivated forms, often referred to as D. variabilis.

The chromosome count of $n=16$ was based on the pollen mother cells of cultivated plants grown from seeds collected at the type locality. This count is the same as roughly half of the named species in the genus. It is considered a diploid among extant species and a tetraploid or "ancient polyploid" when based on $x=8$ for extinct ancestral stocks (Lawrence \& Scott-Moncrieff, 1935). 
Acknowledgments. We thank Andrew M. Saar for preparing the illustration and Carmen Ulloa Ulloa for translating the abstract into Spanish. We also thank Jens Peter Hjerting who accompanied us in Mexico and whose fluency with the Spanish language facilitated our field research. Fieldwork was supported, in part, by the Northern Illinois University Faculty Development Fund to PDS and by the Department of Biological Sciences.

\section{Literature Cited}

Lawrence, W. J. C. \& R. Scott-Moncrieff. 1935. The genetics and chemistry of flower colour in Dahlia: A new theory of specific pigmentation. J. Gen. 30: 154-226.

Sherff, E. E. 1951. Dahlia moorei, a new dahlia (fam. Compositae) from northwestern Hidalgo. Bot. Leafl. 5: $22-24$.

Sørensen, P. D. 1969. Revision of the genus Dahlia (Compositae, Heliantheae-Coreopsidinae). Rhodora 71: 309365. 


\section{$2 \mathrm{BHL}$ Biodiversity Heritage Library}

Saar, Dayle E. and Sorensen, Paul Davidsen. 2000. "Dahlia parvibracteata (Asteraceae, Coreopsideae), a new species from Guerrero, Mexico." Novon a journal of botanical nomenclature from the Missouri Botanical Garden 10, 407-410.

View This Item Online: https://www.biodiversitylibrary.org/item/14670

Permalink: https://www.biodiversitylibrary.org/partpdf/38248

\section{Holding Institution}

Missouri Botanical Garden, Peter H. Raven Library

\section{Sponsored by}

Missouri Botanical Garden

\section{Copyright \& Reuse}

Copyright Status: In copyright. Digitized with the permission of the rights holder.

License: http://creativecommons.org/licenses/by-nc-sa/3.0/

Rights: https://biodiversitylibrary.org/permissions

This document was created from content at the Biodiversity Heritage Library, the world's largest open access digital library for biodiversity literature and archives. Visit BHL at https://www.biodiversitylibrary.org. 